\title{
IN SITU AND EX SITU BIOREMEDIATION OF HEAVY METALS: THE PRESENT SCENARIO
}

\author{
Oindrila PAUL ${ }^{1}$, Amrita JASU ${ }^{1}$, Dibyajit LAHIRI ${ }^{2}$, Moupriya NAG ${ }^{2}$, Rina Rani RAY ${ }^{1^{*}}$ \\ ${ }^{1}$ Department of Biotechnology, Maulana Abul Kalam Azad University of Technology, Haringhata, \\ West Bengal, India \\ ${ }^{2}$ Department of Biotechnology, University of Engineering \& Management, Kolkata, West Bengal, India
}

Received 29 October 2020; accepted 21 December 2020

\author{
Highlights \\ Microbial associated bioremediation techniques. \\ $>$ Use of ANN and computational approach. \\ Use of omics approach.
}

\begin{abstract}
Enhanced population growth, rapid industrialization, urbanization and hazardous industrial practices have resulted in the development of environmental pollution in the past few decades. Heavy metals are one of those pollutants that are related to environmental and public health concerns based on their toxicity. Effective bioremediation may be accomplished through "ex situ" and "in situ" processes, based on the type and concentration of pollutants, characteristics of the site but is not limited to cost. The recent developments in artificial neural network and microbial gene editing help to improve "in situ" bioremediation of heavy metals from the polluted sites. Multi-omics approaches are adopted for the effective removal of heavy metals by various indigenous microbes. This overview introspects two major bioremediation techniques, their principles, limitations and advantages, and the new aspects of nanobiotechnology, computational biology and DNA technology to improve the scenario.
\end{abstract}

Keywords: bioremediation, "in situ" and "ex situ" bioremediation, bioattenuation, heavy metals.

\section{Introduction}

Environmental pollution is increasing rapidly due to urbanization and industrialization. It leads to the rise in toxicity and threat to human life and the environment and becomes a major global concern (Manisalidis et al., 2020). The increase in loads of heavy metals like cadmium (Cd), arsenic (As), chromium (Cr VI), mercury ( $\mathrm{Hg}$ ) and lead $(\mathrm{Pb})$, in aerial, aquatic and terrestrial system results in deterioration of the environment. Enhancement in the concentration of heavy metals within the body causes serious health hazards. Heavy metal contaminations into the environment appear due to both natural and man-made sources. Anthropogenic sources include industrial wastes, metal mining, agricultural practices, automobile emissions and atmospheric deposition (Pazirandeh et al., 1998; Rajendran et al., 2003). Natural resources are affected by contamination due to anthropogenic sources which lead to contamination of agricultural and food products. Various physical and chemical methods exist for the removal of pollutants (Vargas-García et al., 2012). Conventional methods such as excavation, solidification/stabilization are used to remediate heavy metals contaminated site but these technologies permanently do not remove heavy metals. Biological methods are easy to operate and it encourages the establishment of plants on polluted soils. Heavy metals have high density and are toxic at low concentrations (Shazia et al., 2013). Bioremediation is a natural process that involves microorganisms to reduce pollutant concentration. Microorganisms possess a potent role in for maintaining the sustainability of the ecosystem as they adjust themselves to the rapid change of the environment. They possess the ability to evolve life long and they are omnipresent as they bring about its effect to the entire biosphere (Seigle-Murandi et al., 1996). Microbial cells are responsible for various processes that include nitrogen fixation, carbon fixation, sulphur metabolism

${ }^{*}$ Corresponding author. E-mail: raypumicro@gmail.com

Copyright $\odot 2021$ The Author(s). Published by Vilnius Gediminas Technical University

This is an Open Access article distributed under the terms of the Creative Commons Attribution License (http://creativecommons.org/licenses/by/4.0/), which permits unrestricted use, distribution, and reproduction in any medium, provided the original author and source are credited. 
and methane metabolism which on contrary regulated the biogeochemical cycles (Dash \& Das, 2012). The metabolic enzymes being produced by these organisms help in the safe removal of the various types of contaminants by the mechanism of converting complex toxic substances to lesser toxic materials (Dash \& Das, 2012).

The process of bioremediation can be classified based on aerobic and anaerobic conditions, but remediating processes in aerobic conditions are faster compared to anaerobic conditions (Jeyasingh \& Philip, 2005). Type of environment, pollution nature, depth of pollution, location and cost are some of the criteria which are taken into consideration while choosing any bioremediation technique (Frutos et al., 2012; Smith et al., 2015). Apart from these criteria, temperature, $\mathrm{pH}$, nutrient and oxygen concentration determines the success of bioremediation.

Heavy metal contaminated soil or aquatic system can be remediated with the help of "ex situ" and "in situ" techniques. "In situ" bioremediation involves treating soil without excavation. It is a simple process to apply and reduces the risk of contaminants spreading through transport. "In situ" techniques involve minimum technologies for the addition of air, nutrients and microorganisms. "Ex situ" bioremediation involves removing contaminants from the original site, which involves landfill, acid leaching and thermal treatment. A wide spectrum of technologies exists for "ex situ" techniques which are based on different degrees of complexity having a common feature, treatment of excavated soil. "Ex situ" techniques are complex and have a higher cost compared to "in situ" techniques.

This mini-review would focus on various mechanisms of "in situ" and "ex situ" bioremediations of heavy metals by microbial systems. It will focus on the latest systems on machine learning, deep learning and artificial neural networks (ANN) for understanding the mechanisms of bioremediations.

\section{Principle of bioremediation}

Bioremediation is defined as the process where the contaminants present in soil, sediments and groundwater can be biologically degraded to innocuous substances. It requires three essential components like micro-organisms food and nutrients that are together known to be a bioremediation triangle. Microorganisms play an effective role as it metabolizes the chemicals to produce water, carbon dioxide or methane and biomass. Bioremediation depends on many parameters like the nature of pollutants, type of microorganisms present in the soil, $\mathrm{pH}$, moisture content, soil properties, temperature and reduction-oxidation (redox) potential. The main aim of bioremediation is to create the optimum conditions for biologically degrading the contaminants through bio-stimulation (addition of nutrients, aeration, organic substrates etc.) or bioaugmentation (addition of microorganisms) Mostly bioremediation systems operate under aerobic conditions, but when operated under anaerobic conditions it allows microbial organisms to degrade. The techniques involved in bioremediation are more favorable than the traditional methods as it can be implemented on-site, reducing risks for personnel. The technology is more focused on natural processes so the public considers it more acceptable and greener compared to others. The technique is considered cost-effective and it provides a permanent solution that is less expensive compared to other physicochemical methods and has become more prevalent in treating soils contaminated by heavy metals.

Organisms serve as important agents for bioremediation. Pseudomonas putida was firstly patented in the year 1974 as an important agent for the biological remediation of petroleum (Latha \& Reddy, 2013).

\section{Heavy metals toxicity}

Heavy metal toxicity means the potentiality of the metal to bring about detrimental effects on microorganisms that are dependent on the absorbed dose and the bioavailability of the metals (Rasmussen et al., 2000). Heavy metals toxicity includes various mechanisms such as destruction of ion regulation, degradation of enzymatic activity, production of reactive oxygen species (ROS) and degradation of DNA as well as the associated proteins (Patrick \& Violaine, 2014; Hildebrandt et al., 2007). Due to the presence of heavy metals, the biochemical and physiological properties of microorganisms can be altered. Chromium (Cr) and Cadmium $(\mathrm{Cd})$ can bring about oxidative denaturation and damage of microorganisms resulting in weakening the bioremediation capacity of the microbial cells.

$\mathrm{Cr}$ (III) can change both the structure and activity of enzymes by reacting with their thiol and carboxyl groups (Cervantes et al., 2001). Heavy metals like copper, $\mathrm{Cu}(\mathrm{I})$ and $\mathrm{Cu}(\mathrm{II})$ catalyze the production of ROS by Fenton and Haber-Weis reactions, which will itself act as soluble electron carriers and causes serious injury to DNA, lipids, cytoplasmic molecules and other proteins.

Cadmium $(\mathrm{Cd})$ and Lead $(\mathrm{Pb})$ can damage cell membranes, destroys the structure of DNA, and have a dangerous impact on microbes. They displace the metals from their native binding sites or ligand interactions (Olaniran et al., 2013).

Aluminum (Al) is responsible for the damage of DNA and can stabilize superoxide radicals. Heavy metal changes the configuration of enzymes by stopping their vital enzymatic functions with substrates by competitive or noncompetitive interactions (Patrick \& Violaine, 2014).

\subsection{Effect of heavy metal on environment}

Heavy metals bring about negative impact on all the biotic components of the ecosystem including human being and its desired species. Various heavy metals like copper, cadmium, nickel, lead and methyl mercury produce serious adverse effects upon the environment above a threshold concentration (Hopkins et al., 2000; LeFauve \& Connaughton, 2017). These metals generate negative impacts on the germination of seeds, metabolism of plants, 
resistance mechanisms and growth (Aydinalp \& Marinova, 2009). It has also been observed that accumulation of heavy metals results in oxidative stresses on algae leading to the reduction in their chlorophyll contents (Pinto et al., 2003). Metals like arsenic and barium can cause nausea, diarrhea, abdominal pain, decreased blood pressure alongwith lower counts in blood cells. Exposure to zinc is known to have erosive effects on skin (Ismail et al., 2013). Heavy metals like silver and selenium are reported to have abdominal, respiratory and neurological abnormalities causing arygria and selenosis respectively (Martin \& Griswold, 2009).

\subsection{Heavy metal toxicity in human}

Heavy metals bring about several negative impacts upon human health mainly on kidney, liver, respiratory system and nervous system (Godwill et al., 2019). Some of the heavy metals are highly carcinogenic (Godwill et al., 2019), delays growth within human, brings about disruption in the bioregulatory systems resulting in the development of neurodegenerative diseases, chronic fatigue and Alzheimer's diseases (Poey \& Philibert, 2000). It has been observed that lead and hexavalent chromium can bring about severe hemotoxic effect (Ray, 2015, 2016). Lead and mercury are also responsible for the development of autoimmunity phenomenon like rheumatoid arthritis, nervous problem, kidney and circulatory system (Lauwerys et al., 2007).

\section{Microbial bioremediation of heavy metals}

Microbial bioremediation of heavy metals is an effective and ecofriendly way to achieve a pollution free environment by reducing industrial exploitations of chemical methods (Rajendran et al., 2003). Metals that play an important role in various metabolic and redox functions include chromium $(\mathrm{Cr})$, calcium $(\mathrm{Ca})$, copper $(\mathrm{Cu})$, manganese $(\mathrm{Mn})$, magnesium $(\mathrm{Mg})$, sodium $(\mathrm{Na})$, nickel $(\mathrm{Ni})$ and zinc $(\mathrm{Zn})$. Metals such as cadmium $(\mathrm{Cd})$, gold $(\mathrm{Au})$, aluminum $(\mathrm{Al})$, mercury $(\mathrm{Hg})$ and silver $(\mathrm{Ag})$ have no biological role and are toxic to soil microbes. In the process of adsorption of heavy metals, temperature plays an important role. As temperature increases, the rate of adsorbate diffusion across the external boundary layer also resulting in the increased solubility of heavy metals increases which improves the bioavailability of heavy metals (Bandowe et al., 2014). Chromium exists in the environment in two forms: $\mathrm{Cr}^{6+}$ in highly toxic form and $\mathrm{Cr}^{3+}$ in less soluble toxic form. $\mathrm{Cr}^{3+}$ which exists as a trivalent form of chromium is an essential trace element that acts as a cofactor for enzymes in various biological systems e.g. insulin receptor tyrosine kinase gets activated (Davis \& Vincent, 1997). $\mathrm{Cr}^{6+}$ which is toxic and mutagenic can be reduced to a less toxic trivalent form by several bacteria (Garbisu et al., 1998). Chromate $\left(\mathrm{Cr}^{6+}\right)$ can be reduced to non-toxic $\mathrm{Cr}^{3+}$ and chromate efflux. Chromate efflux is regulated by the sulphate uptake system as accumulation interferes with sulphate metabolism (Peitzsch et al., 1998). Soil and marine sediments which contain several anaerobic and facultative bacteria are capable of reducing $\mathrm{Cr}^{6+}$ to $\mathrm{Cr}^{3+}$ (Francis, 1990). Anaerobic bacteria which have the ability to reduce iron and sulphate can indirectly reduce $\mathrm{Cr}^{6+}$ via $\mathrm{Fe}(\mathrm{II})$ and hydrogen sulphide (HS-) respectively (Davis \& Vincent, 1997; Pettine et al., 1998).

\section{Factors affecting bioremediation of heavy metals by microorganisms}

The heavy metals to be acting as stimulator or inhibitor to microorganisms is determined by the total available concentration of heavy metals, chemical form in which the metals exist and the various redox potential. Various factors of environment like $\mathrm{pH}$, temperature, low molecular weight organic acids and humic acids regulate the mechanisms of transportation, transformation, the bioavailability of heavy metals and valence state of the heavy metals towards the microbial cells. Enhancement in the concentration of hydrogen ions results in the development of a positive charge upon the adsorbent surface resulting in the reduction of attraction between the adsorbent and metal cations causing the development of metal toxicity. The adsorption of heavy metals is considerably dependent upon the temperature thus enhancement in temperature

Table 1. Factors affecting bioremediation by the microorganisms (Boopathy, 2000)

\begin{tabular}{|l|l|}
\hline \multicolumn{1}{|c|}{ Factors } & \multicolumn{1}{c|}{ Activities } \\
\hline Microbial cells & $\begin{array}{l}\text { Induction of enzymes, production of toxic metabolites, mutations, horizontal gene transfer, help in the } \\
\text { proliferation of bacterial cells }\end{array}$ \\
\hline Substrates & $\begin{array}{l}\text { The structure and chemical composition of the contaminants, variations in the concentrations of the } \\
\text { contaminants, amount of toxicity of the contaminants, solubility of the contaminants }\end{array}$ \\
\hline Environmental & Depletion of the preferential substrates, inhibitory environmental conditions, lack of nutrients \\
\hline $\begin{array}{l}\text { Limitations of Mass } \\
\text { Transfer }\end{array}$ & $\begin{array}{l}\text { Oxygen diffusion and solubility, variation is solubility and miscibility in water and amount of nutrient } \\
\text { diffusion }\end{array}$ \\
\hline $\begin{array}{l}\text { Co-Metabolism Vs } \\
\text { Growth substrates }\end{array}$ & $\begin{array}{l}\text { Interactions among the microbial cells, variation in the concentration and alternate carbon sources } \\
\text { available }\end{array}$ \\
\hline $\begin{array}{l}\text { Aerobic and Anaerobic } \\
\text { Biological processes }\end{array}$ & $\begin{array}{l}\text { Site comprising of various microbial populations, redox potential, availability of various types of electron } \\
\text { acceptors }\end{array}$ \\
\hline
\end{tabular}


increases the rate of diffusion across the external boundary layer. The increase in temperature enhances the solubility of the metals thus enhances the bioavailability of these metals (Bandowe \& Meusel, 2017). Thus, the increase in the temperature increases the activity of the microorganisms thus increases the metabolism of the microbial systems accelerating the rate of bioremediations (Table 1).

\section{Types of bioremediation ["ex situ" and "in situ" bioremediation]}

Both "in situ" and "ex situ" bioremediation approaches depend on microbial metabolism. The methods of "in situ" bioremediation are preferred for restoring contaminated soil and water environments (Jørgensen et al., 2007) as they involve the mechanisms of removing target pollutants from the natural environment with the help of the metabolic potential of the microbial systems without the process of excavation of contaminated samples (Fruchter \& Demian, 2002). On the other hand, the "ex situ" bioremediation is the process of intervention that brings about degradation of chemical pollutants, present within the excavated samples (Carberry \& Wik, 2001). The techniques of "ex situ" remediation appear to be more expensive in comparison to that of "in situ" techniques. These mechanisms of bioremediation show significant differences in their experimental controls and the consistency of the process outcome. The process of "ex situ" bioremediation can be manipulated with the help of various physicochemical treatments as it is carried out in a non-natural environment (Kim et al., 2005). The mechanism of "in situ" remediation is mainly targeted to the restoration of the normalcy of the contaminated environment by the usage of various treatment technologies.

\section{1. "Ex situ" bioremediation techniques}

This involves excavation or removal of contaminated soil and subsequently transporting them to another site for treatment. The geographical location of the polluted site, cost of treatment, type of pollutant, depth of pollution and degree of pollution are the main criteria for "ex situ" bioremediation techniques. "Ex situ" bioremediation techniques are easier to control and are used to treat a wider range of toxins and soils. Here the material is typically mixed, well-aerated and plenty of nutrients are available so the breakdown of contaminants is must faster compared to "in situ" techniques.

\subsubsection{Biopile}

Biopile mediated bioremediation involves heaping contaminated soils into piles, followed by nutrient amendment and aeration to augment bioremediation by increasing microbial activities. Different terms of biopiles such as bioheaps, biocells, biomounds are used for remediating petroleum contaminants present in soil and sediments. Nutrient, temperature, moisture, $\mathrm{pH}$ are adequately controlled to enhance biodegradation and for this constructive features use of this particular "ex situ" technique is increasing (Whelan et al., 2015). Biopile is considered as a better pollutant removal strategy as it has higher efficiency compared to land farming and composting based on mass transfer of water, nutrients and air. This technique is used to remove heavy metals from soil (Tampouris et al., 2001). It can be applied to remediate extremely polluted environments such as very cold regions. It can also treat large volumes of polluted soil in limited space. This process can be easily scaled up to a pilot system for achieving the same performance which was obtained during laboratory studies (Chemlal et al., 2013). Sieving and aeration of contaminated soil are important to maintain the efficiency of biopile (Delille et al., 2008).

\subsubsection{Windrow}

To enhance bioremediation, windrows focus on periodically turning the piled polluted soil by enhancing the rate of degradation of indigenous or transient hydrocarbonoclastic bacteria observed within polluted soil. The periodic turning of polluted soil increases the rate of bioremediation by increasing aeration with the addition of water, uniform distribution of nutrients, pollutants and microbial degrading activities which can be performed by assimilation, mineralization and biotransformation In windrows, the release of greenhouse gas, methane $\left(\mathrm{CH}_{4}\right)$ was due to the development of anaerobic zones within polluted soil (Hobson et al., 2005). Windrow treatment is not a suitable option for remediating soil polluted with toxic volatiles as it involves periodic turning. Humic substances were found to be effective for the removal of heavy metals like $\mathrm{Cd}$, Ni. (Zhang et al., 2019). The fractionation of metals like $\mathrm{Cu}, \mathrm{Zn}, \mathrm{Fe}$ and $\mathrm{Mn}, \mathrm{Cd}$ are accomplished by this method (Achiba et al., 2009).

\subsubsection{Land-farming}

Landfarming requires less equipment for operation and low-cost characteristics. The polluted soils are either tilled or excavated, but the site of treatment depends on the type of bioremediation. The production of leachate compounds must be taken into account while applying land farming as a leachate collection and treatment system is required depending on the nature of the site, to prevent groundwater contamination. Landfarming creates air pollution problems and health risks for the workers due to the emission of volatile organic compounds (VOCs), which can be reduced by covering the area with a greenhouse structure for minimizing the dust. Bioremediation proceeds without excavation, when a pollutant lies $<1 \mathrm{~m}$ below the ground surface, whereas the pollutant, is transported to the ground surface for bioremediation when it lies $>1.7 \mathrm{~m}$ (Nikolopoulou et al., 2013). Tillage enhances bioremediation by stimulating the activity of autochthonous microorganisms during landfarming. The major operations of tillage are the addition of nutrients (nitrogen, phosphorus and potassium), irrigation and aeration. Both tillage and irrigation having appropriate biological activity enhance 
the rate of bioremediation by increasing the heterotrophic bacterial counts. Microbial dehydrogenase activity can be used as a biological parameter in landfarming as it was observed to be a good indicator of biostimulation treatment (Silva-Castro et al., 2015).

Though landfarming is the simplest bioremediation technique, it has some limitations. It requires a large operating space, additional cost due to excavation, microbial activity reduction due to unfavorable environmental conditions and reduced efficiency in inorganic removal of pollutants (Khan et al., 2004; Maila \& Cloete, 2004). These limitations make the technique time-consuming and less efficient compared to other ex situ remediation techniques.

\subsubsection{Bioreactor}

Bioreactor, as the name suggests, is a vessel designed for the removal of pollutants from wastewater or pumped groundwater using microbes. It is an "ex situ" biological processing system used for the treatment of contaminated soils in solid and liquid (slurry) phases. The different operating modes of the bioreactor are batch, fed-batch, sequencing batch, multistage and continuous. The operating mode of the bioreactor is based on the total economy of the market and capital expenditure. For providing optimum growth conditions, bioreactor supports natural processes of cells by maintaining their environment. Temperature, $\mathrm{pH}$, moisture, inoculum concentration, aeration rate, agitation rate and substrate concentration are the parameters important for bioreactor. The parameters in a bioreactor can be controlled and manipulated which implies that the biological reactions present within can be augmented to effectively reduce bioremediation time. The limiting factors of bioremediation process in a bioreactor are addition of nutrients, controlled bioaugmentation, increased bioavailability of pollutants and mass transfer. Heavy metal removal in an Anaerobic Upflow (ANFLOW) bioreactor is similar to an ion exchange process, where a saturation transient begins at the bottom of the column and moves upward (Rivera, 1983). About $80 \%$ for $\mathrm{Cu}(\mathrm{II})$, $98 \%$ for $\mathrm{Pb}(\mathrm{II}), 50 \%$ for $\mathrm{Ni}(\mathrm{II})$ and $77 \%$ for $\mathrm{Zn}$ (II) bioremediation was found to be achieved in a Membrane bioreactor (MBR) system (Katsou et al., 2011). It was found that the fixed bed bioreactors was able to increase the efficiency towards the removal of metals $\left(\mathrm{Cu}^{2+}, \mathrm{Pb}^{2+}, \mathrm{Cd}^{2+}\right.$, $\mathrm{Co}^{2+}, \mathrm{Ni}^{2+}, \mathrm{Zn}^{2+}, \mathrm{Mn}^{2+}$, and $\mathrm{Fe}^{3+}$ ) in polluted environmental samples by a strain of Pseudomonas aeruginosa to control many harmful health hazard substances (Ibrahim et al., 2019). On the other hand, removal of heavy metals including nickel, arsenic, cadmium, antimony and lead by membrane bioreactor was investigated by Komesli (2014). Aftab et al. (2017) effectively removed Chromium $(\mathrm{Cr})$ and Lead $(\mathrm{Pb})$ metals, from wastewater by osmotic membrane bioreactor (OMBR). About 90\% removal of heavy metals (nickel and chromium) was done through biosorption in fixed packed-bed bioreactor at alkaline $\mathrm{pH}$ for 20 days (Barros et al., 2006).
Due to some reasons, bioreactor- based bioremediation is not a particular practice for heavy metal removal. Firstly, it requires more manpower, capital and safety measures to treat the large volume of polluted soils or other substances and transporting pollutants to the site of treatment, which make this technique cost ineffective (Philp \& Atlas, 2005). Secondly, having so many bioprocess variables of a bioreactor, if any variable is not properly controlled it becomes a limiting factor which results in the reduction of microbial activities making the technique less effective. Thirdly, pollutants respond to different bioreactors in different way so the availability of the most suitable design is of utmost importance.

\section{2. "In situ" techniques of bioremediation}

"In situ" bioremediation techniques involve treating the contaminants at the site of pollution where they can be biologically degraded under natural conditions. This technique does not require any excavation, so it involves much less effort of transportation and physical displacement than required for "ex situ" bioremediation techniques. Apart from removal of heavy metals, "in situ" bioremediation is used for the treatment of dyes, chlorinated solvents and hydrocarbon polluted sites (Kim et al., 2014; Frascari et al., 2015; Folch et al., 2013; Roy et al., 2015). But, "in situ" treatment generally requires longer time and there is less certainty about the uniformity of treatment because of the variations in soil characteristics and efficacy of the process is very difficult to verify. For a successful "in situ" bioremediation, moisture content, temperature, $\mathrm{pH}$, oxygen supply and nutrient supply are the major environmental conditions that need to be suitable, of which, the availability of molecular oxygen is the major problem.

\subsubsection{Intrinsic methodology of bioremediation}

The mechanism of natural attenuation or intrinsic bioremediation is an inherent technique of "in situ" remediation process which deals with both microbial aerobic and anaerobic processes to remediate the pollutants or contaminants without using any external input. This process is the first choice for bio treatment as it does not require any intervention. The method allows the ecosystem to revert to its original condition, avoids damaging the habitat and enables detoxification of toxic compounds. The term, monitored natural attenuation (MNA) represents a more comprehensive approach to intrinsic bioremediation. Bioavailability is a crucial step in case of intrinsic bioremediation, as in this case biological materials are used to investigate the presence of heavy metals. The major disadvantage of intrinsic bioremediation is the prolonged time it needs to reach the target level.

\subsubsection{Bioattenuation}

The technique relies on transforming pollutants to less harmful forms or immobilized state (Smets \& Pritchard, 2003). On the basis of physical and chemical principles, 
the costs are $80-90 \%$ lower than other clean-up technologies (Davis et al., 1994; Mulligan \& Yong, 2004). Fauziah et al. (2017) reported about the successful removal of metals like $\mathrm{As}, \mathrm{Ni}$ and $\mathrm{Al}$ by proteobacteria mediated bioattenuation, whereas Acinetobacteria were found to take part in bioattenuation process for natural removal of metals like U, Al, Cd, Co, Cu, Mn, Ni (Schmidt et al., 2005).

\subsubsection{Bioaugmentation}

Bioaugmentation, the process where enriched consortia or strains that are added as the required microbial populations do not exist in sufficient number for degrading the target compounds (Robles-González et al., 2008). Hence for achieving success, mixed cultures having variety of microorganisms are used in practice (Di Toro et al., 2006). Various biotic and abiotic factors responsible for the purpose of effective bioaugmentation (Bento et al., 2005); which includes cadmium enriched soil by a newly isolated strain of Bacillus sp. and a Streptomyces sp. (Lebeau \& Jézéquel, 2008) and removal of heavy metals $(\mathrm{Ni}, \mathrm{Pb}$, and $\mathrm{Zn}$ ) by a consortium of filamentous fungi using bioaugmentation procedure are reported.

Although various adverse biotic and abiotic factors affect autochthonous microorganisms and they may alter their surroundings by releasing organic compounds, the success of bioaugmentation can be improved by selecting the proper operating strategies, aimed at improving the survival and long-term efficiency of the inoculated microbial species.

\subsubsection{Biostimulation}

Biostimulation for heavy metals depends on the supply of nutrients (carbon, nitrogen, phosphorus), temperature, oxygen, $\mathrm{pH}$, redox potential and concentration and type of organic pollutant for accelerating the microbial turnover of chemical pollutants (Carberry \& Wik, 2001; Bundy et al., 2002; Atagana, 2008; Al-Sulaimani et al., 2010).

Addition of biodegradable compounds which act as primary substrates is another strategy of biostimulation where the pollutant is degraded as secondary substrate but at acceptable rates.

Temperature increases biomass activity which plays a positive role in biostimulation, and temperature control can be achieved only in engineered systems such as slurry bioreactors and contained vessel composting. Fulekar et al. (2012), carried out a biostimulation study for removing $\mathrm{Fe}, \mathrm{Cu}$, and $\mathrm{Cd}$ using aerobic bacteria cultured from isolated heavy metals, Kanmani et al. (2012) also performed biostimulation for $\mathrm{Cr}$ removal by using heterogeneous groups of bacteria isolated from contaminated sites.

\subsubsection{Bioslurping}

Bioslurping involves the simultaneous application of vacuum enhanced recovery, soil vapor extraction and bioventing to achieve soil and groundwater remediation by indirectly incorporating oxygen and stimulating biodegradation of contaminants (Gidarakos \& Aivalioti, 2007). It is designed for free product recovery such as light non aqueous phase liquids (LNAPLs) without extracting vast quantities of ground water. The system uses a "slurp" tube that extends into the free product layer that draws up liquid (including soil gas and free product) from the layer in a way similar to a straw draws liquid from any vessel. Bioslurping of cadmium ions from soils was done using Arabidopsis helleri (However, the technique is not suitable for remediating soil with low permeability and moisture content as it dries out the soil and curbs the effectiveness of bioremediation). The technique also can not treat residual contamination in saturated soils and is applicable at sites with water table greater than 30 feet. The major concern of this particular "in situ" technique is the establishment of vacuum on fluctuating water table and deep high permeable site which creates saturated soil lenses that are difficult to aerate (Figure 1).

\subsubsection{Bioventing}

The ultimate goal in bioventing is to achieve microbial transformation (Table 2) of pollutants to a harmless state by addition of nutrients and moisture to enhance bioremediation (Philp \& Atlas, 2005). The two basic criteria for successful bioventing are to maintain aerobic conditions and to obtain reasonable biodegradation rates, natural hydrocarbon degrading microorganisms must be present in enough concentrations and hence air injection rate is one of the main parameters for pollutant dispersal. "In situ" treatment of heavy metals generally involves pumping oxygen/nutrients (bioventing/biostimulation) into the soil (Kapahi \& Sachdeva, 2019).

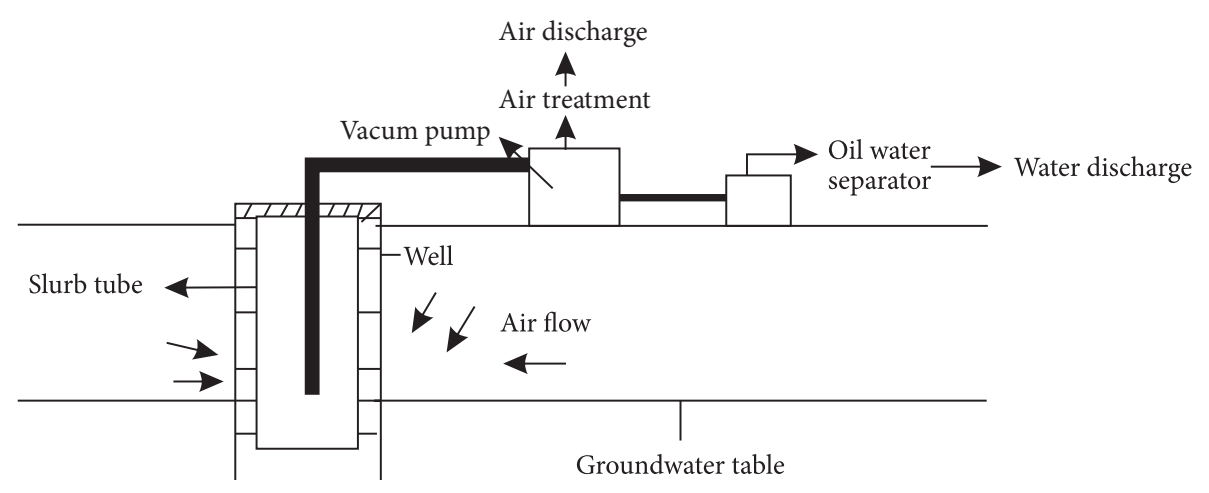

Figure 1. "In situ" bioremediation by the technique of Bioslurping 
Table 2. Potential mechanisms of microbial transformation of metals

\begin{tabular}{|c|c|c|c|}
\hline Types of Metabolite Reaction & Microorganisms Involved & $\begin{array}{l}\text { Potential of the } \\
\text { Microorganisms }\end{array}$ & Reference \\
\hline \multicolumn{4}{|c|}{ Redox Reaction } \\
\hline Oxidation and Reduction Reaction & $\begin{array}{l}\text { Leptospirillum ferrooxidans, } \\
\text { Acidithiobacillus thiooxidans, } \\
\text { Rhodococcus sp., Streptomyces } \\
\text { lividans sp. }\end{array}$ & $\begin{array}{l}\text { Enhances the mobility of As, } \\
\mathrm{Cd}, \mathrm{Cu}, \mathrm{Hg} \text { and } \mathrm{Zn}\end{array}$ & Yang et al. (2012) \\
\hline \multicolumn{4}{|c|}{ Polymeric Substances } \\
\hline Glomalin & Glomus mosseae & Immobilizes $\mathrm{Pd}, \mathrm{Cd}$ and $\mathrm{Cu}$ & González-Chávez et al. (2004) \\
\hline Extracellular Polymeric Substances & Azotobacter sp. & Immobilized $\mathrm{Cr}$ and $\mathrm{Cd}$ & Joshi and Juwarkar (2009) \\
\hline \multicolumn{4}{|c|}{ Biosurfactant } \\
\hline \multicolumn{4}{|c|}{ Organic Acid } \\
\hline 5-ketoglutaric acid, Gluconic acid & $\begin{array}{l}\text { Pseudomonas aeruginosa, } \\
\text { Gluconacetobacter } \\
\text { diazotrophicus }\end{array}$ & $\begin{array}{l}\text { Solubilized } \mathrm{ZnO}, \mathrm{Zn}_{3}\left(\mathrm{PO}_{4}\right)_{2}, \\
\mathrm{ZnCO}_{3}\end{array}$ & Saravanan et al. (2007) \\
\hline \multicolumn{4}{|c|}{ Siderophores } \\
\hline Azotobactin, Azoto chelin & Azotobacter vinelandii & Helps in the acquisition of Mo & Wichard et al. (2009) \\
\hline Coelichelin and Desferrioxamine & Streptomyces tendae & $\begin{array}{l}\text { Enhanced uptake rate of Fe } \\
\text { and Cd by plants }\end{array}$ & Dimkpa et al. (2009) \\
\hline
\end{tabular}

At the vadose zone, bioventing enhances microbial degradation process by moderately injecting air (Figure 2) whereas soil vapour extraction (SVE) relies on maximization of volatile organic compound volatilization (Magalhães et al., 2009). In soil-vapour extraction, the flow rate of air is higher compared to that of bioventing (Baker \& Moore, 2000).

\subsubsection{Biosparging}

This technique involves injection of air into soil subsurface to enhance the rate of biological degradation of contaminants by naturally occurring bacteria. The effectiveness of biosparging depends on two factors: pollutant biodegradability and soil permeability (Philp \& Atlas, 2005). The bacteria, in stressful condition produce metal-adsorbing materials, which chemically interact with pollutants causing their precipitation. These contaminants get degraded during biosparging as oxygen input creates aerobic condition suitable for the degradative action of indigenous microbes (Adams \& Reddy, 2003). This results in the raise

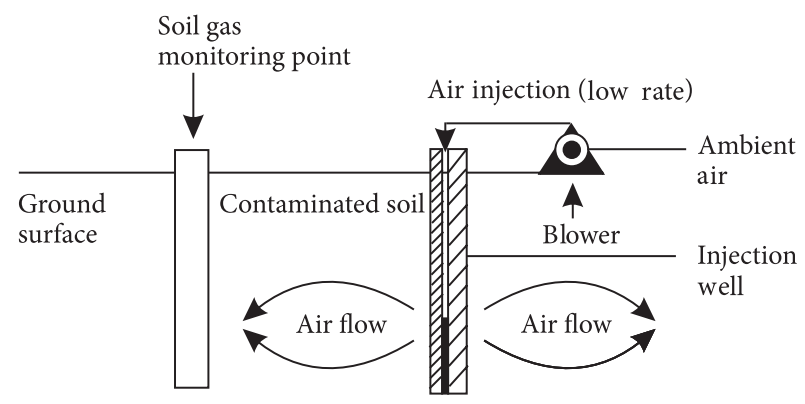

Figure 2. "In situ" bioremediation by the technique of bioventing in concentration of dissolved oxygen, redox potentials, sulphate, nitrate and reduction in methane, sulphide and iron (Table 2).

\subsubsection{Permeable reactive barrier (PRB)}

This technique also referred to as permeable reactive treatment zone (PRTZ), is used for remediating contaminated groundwater. The wall is "permeable" which means that groundwater can flow through it. This process involves in remediating the polluted ground water that usually comprise of chlorinated compounds and heavy metals. In this technique, the reactive barrier (medium) used is made of zero valent iron which is submerged in the trajectory of the polluted groundwater (García et al., 2014; Zhou et al., 2014). When the polluted water flows through the barrier, pollutants get trapped and undergo various reactions resulting in the flow of clean water (Thiruvenkatachari et al., 2008; Obiri-Nyarko et al., 2014). The barriers are quite reactive enough to trap the pollutants and allow the flow of water but not pollutants (De Pourcq et al., 2015). For removal of contaminants from groundwater, there are four types of reactive processes used in PRB: abiotic reduction, biotic reduction-oxidation, chemical precipitation and sorption of ion exchange.

Researchers are more focused on coupling PRB with electrokinetics method for treating various kinds of pollutants (García et al., 2014; Mena et al., 2015). Maximum removals of $\mathrm{Zn}, \mathrm{Pb}, \mathrm{Cu}$ and $\mathrm{Cd}$ were achieved under different experimental conditions. The voltage gradient and processing time were shown to have significant effects on the removal of $\mathrm{Cu}$ and $\mathrm{Cd}$, whereas the addition of the oxalic acid had a more significant influence on the removal of $\mathrm{Pb}$ (Huang et al., 2015). The effectiveness of 
the technique depends on the biogeochemical and hydrogeological conditions, contaminant distribution and cost. The effectiveness of the technique can be increased by improving PRB designs and advanced site characterization methods (Gibert et al., 2013). The use of iron sulphide $(\mathrm{FeS})$ barrier will help to overcome the problems faced due to the use of zero valent iron (ZVI) (Henderson \& Demond, 2013).

\subsection{Phytoremediation}

Phytoremediation or plant-based bioremediation is a very cost-effective, ecofriendly and prominent technique which has been used for years (Azubuike et al., 2016). This technique involves the use of plants and associated microorganisms to completely remediate the selected contaminants from soil, sediments, sludge, wastewater and groundwater. In phytoremediation, based on the type of pollutants (organic or elemental) there are several mechanisms available such as filtration, degradation, accumulation or extraction, stabilization and volatilization. Organic pollutants such as hydrocarbons and chlorinated compounds can be removed by degradation, stabilization, rhizoremediation, volatilization and mineralization (Meagher, 2000). Elemental pollutants such as radionuclides and toxic heavy metals can be removed by transformation, extraction and sequestration.

All plants have the ability to accumulate essential metals (such as $\mathrm{Ca}, \mathrm{Cu}, \mathrm{Co}, \mathrm{Mg}, \mathrm{Mn}, \mathrm{Na}, \mathrm{K}, \mathrm{Zn}, \mathrm{Se}$ ) as well as non-essential metals (As, Au, Cd, Cr, Pb, Hg, Sb, Pd, Pt) from the soil. Non-essential metals have no known biological function. While choosing a plant as a phytoremediator, some factors to be considered are root system (tap or fibrous) depending on the depth of the existence of pollutant, plant survival based on the prevailing environmental conditions, growth rate of the plant and time required to accomplish the desired level of cleanliness. Plants should be resistant to pests and diseases (Lee, 2013). The process of removal of contaminants by plants involves: uptake by passive process, translocation from roots to shoots which is carried out by flow of xylem and accumulation in shoot (San Miguel et al., 2013). Both translocation and accumulation depend on transpiration. Plants which grow in any polluted site are good phytoremediators. Hence, optimizing the remediation potential of plants growing in any polluted sites by either bio stimulation or by bioaugmentation with exogenous or endogenous plant rhizobacteria is of immense importance. Plant growth promoting rhizobacteria (PGPR) which play an important role in phytoremediation, enhance biomass production and help the plant to tolerate the stress of heavy metals and other unfavorable soil conditions (Yancheshmeh et al., 2011; deBashan et al., 2012). It has been reported that Zea mays and Brachiaria mutica act as potential phytoremediators of heavy metal contaminated soils (Ijaz et al., 2015; Tiecher et al., 2016).

Rhizoremediation which is an elemental component of phytoremediation can occur naturally or can be triggered by using plant growth promoting microorganisms. The presence of contaminants in soil which is deeper than the root zone of plants requires excavation or selection of trees with deeper roots. Another type of phytoremediation involving trees is Dendroremediation, which is useful in attenuating certain pollutants such as trichloroethylene and 2,4,6-trinitrotoluene from groundwater and soil. Various secondary plant metabolites (SPMEs) produced by plants includes phytohormones/phytoalexins, phytosiderophores, root exudates and phytoanticipins.

Phytoremediation has various advantages, like it restores habitat, reduce remedial costs, low installation and maintenance cost, cleanup the contaminants in place rather than transporting the problem to another site. In phytoremediation, soil fertility might be improved due to the input of organic matter (Mench et al., 2009). The microbes associated with the rhizosphere of the plants play an important role in the mechanism of phytoremediation by changing the bioavailability through alterations in $\mathrm{pH}$, redox potentials and release of some chemicals like chelators such as organic acids, siderophores, biosurfactants etc. (Miransari, 2013).

\subsection{Mycoremediation}

Fungi play an important role in the mechanism of remediating contaminants within the environment and help in the restoration of normalcy from the weakened condition. The process of mycofiltration shows similarity to the filtration of toxic substances by the use of the fungal mycelia. The various types of fungi including endophytic, saprophytic and mycorrhizal help in the recovering of the soil-water ecosystem thus help in balancing the living population. Various types of extracellular enzymes are produced by the myecelium which helps in the breakdown of the cellulose, lignin and other types of the building blocks of the plant fibres. The mechanism of mycoremediation utilizes the right type of fungal species in remediating a specific type of pollutant (Stamets, 2005). Various studies showed that fungi like Penicillium sp., Ganoderma lucidum, Cladosporium resinae, Aureobasidium pullulans, Aspergillus niger, Rhizopus arrhizus and Trametes versicolor can be effectively used in the process of remediating the heavy metals (Loukidou et al., 2003; Say et al., 2003; Taştan et al., 2010). Studies also showed that Aspergillus versicolor help in remediating chromium from waste water effluents.

\subsection{Cyanoremediation}

The influx of heavy metals like $\mathrm{Cd}, \mathrm{Ni}$ and $\mathrm{V}$ into the atmosphere occurs at much faster rate in comparison to the degradation by natural processes. This results in the accumulation of toxic metals within various ecosystems. Various organisms like bacteria, green algae (Deng et al., 2007), microalgae (Norström et al., 2004) and blue-green algae (Tripathi et al., 2008; Yin et al., 2012) has played an effective role in treating the contaminated wastes being present within the aquatic eco-system. The mechanism of 
cyanoremediation of heavy metals played an effective role in controlling pollution (Yin et al., 2012).

The degradation of heavy metals was achieved by the use of varieties of microbes (Table 3).

\subsection{Nanoparticle associated bioremediation}

An emerging "in situ" technology is nanoremediation, to reduce the source and/or to manage the contaminant plume along the pathway. Nanoparticles derived from plants, fungi and bacteria play an important role in remediating environmental toxic wastes. This mechanism is also known as Nanobioremediation (NBR), which is an emerging field of remediating toxic wastes being present within the nature. Various roles are played by different types of nanomaterials (NM) or nanoparticles (NPs) or nanostructure materials, nanocomposites or nanoclusters in the mechanism of bioremediation (Anjum et al., 2016; Kardam et al., 2012). The nanoparticles prove to be effective agents in cleaning up of the environmental pollutants although possessing zero-valency since they can easily penetrate up to the region of contamination where other types of microparticles do not possess the ability to reach. They possess higher reactivity to the contaminants in comparison to the other types of the microsized particles being used for clearing of the contaminants.

\section{Artificial neural network (ANN) mediated bioremediation}

ANN is a type of computational simulation based on mathematical models which works on the basis of the neurological functions of the brain (Manahan, 2010). The Application of ANN involves mathematical modelling that can be used for the purpose of quantification of $\mathrm{Cr}$ concentration with the dwarf bean and the amount of phytoremediation being performed by the plant (Hattab et al., 2013).

Table 3. Heavy metal bioremediation by microbes

\begin{tabular}{|c|c|c|c|}
\hline $\begin{array}{l}\text { Type of } \\
\text { Microbes }\end{array}$ & Name of the Species & $\begin{array}{l}\text { Heavy Metal } \\
\text { Remediated }\end{array}$ & Reference \\
\hline \multirow{11}{*}{ Bacteria } & Bacillus cereus & $\mathrm{Cr}$ & Dong et al. (2013) \\
\hline & $\begin{array}{l}\text { Escherichia coli, Pseudomonas sp., Micrococcus, Bacillus, } \\
\text { Streptococcus, Salmonella }\end{array}$ & $\mathrm{Fe}, \mathrm{Cu}, \mathrm{Cd}$ & Fulekar et al. (2012) \\
\hline & Bacillus cereus & $\mathrm{Cr}$ & Kanmani et al. (2012) \\
\hline & Bacillus cereus & $\mathrm{Cd}, \mathrm{Zn}$ & Hrynkiewicz et al. (2012) \\
\hline & Pseudomonas aeruginosa & $\mathrm{U}$ & Choudhary and Sar (2011) \\
\hline & Kocuria flava & $\mathrm{Cu}$ & Achal et al. (2011) \\
\hline & Bacillus sp. & $\mathrm{Cd}, \mathrm{Cu}, \mathrm{Pb}$ & Guo et al. (2010) \\
\hline & Pseudomonas and Bacillus & $\mathrm{U}$ & Kumari and Singh (2011) \\
\hline & Rhizobacteria sp, Bradyrhizobium sp. & $\mathrm{Cd}, \mathrm{Pb}, \mathrm{Cu}$ & Dary et al. (2010) \\
\hline & Burkholderia sp. & $\mathrm{Cd}, \mathrm{Pb}$ & Jiang et al. (2008) \\
\hline & Pseudomonas veronii & $\mathrm{Cd}, \mathrm{Zn}, \mathrm{Cu}$ & Vullo et al. (2008) \\
\hline \multirow{6}{*}{ Fungi } & Rhizopus, Penicillium, Aspergillus, Mucor & $\mathrm{Fe}, \mathrm{Cu}, \mathrm{Cd}$ & Fulekar et al. (2012) \\
\hline & Cladonia rangiformis & $\mathrm{Pb}$ & Mani and Kumar (2013) \\
\hline & Aspergillus fumigatus & $\mathrm{Pb}$ & Mani and Kumar (2013) \\
\hline & Penicillium sp., Ganoderma lucidum & $\mathrm{Ar}$ & Mani and Kumar (2013) \\
\hline & Penicillium canescens & $\mathrm{Cr}$ & Mani and Kumar (2013) \\
\hline & Aspergillus versicolor & $\mathrm{Ni}, \mathrm{Cr}, \mathrm{Cu}$ & Mani and Kumar (2013) \\
\hline \multirow{7}{*}{ Algae } & Spirulina sp. and Spirogyra sp. & $\mathrm{Zn}, \mathrm{Cu}, \mathrm{Fe}, \mathrm{Mn}, \mathrm{Cr}, \mathrm{Se}$ & Mani and Kumar (2013) \\
\hline & $\begin{array}{l}\text { Rhizoclonium sp., } \\
\text { Oedogonium sp. and Hydrodictylon sp. }\end{array}$ & As, $\mathrm{V}$ & Mani and Kumar (2013) \\
\hline & Spirullina sp. and Spirogyra sp. & $\mathrm{Cu}, \mathrm{Fe}, \mathrm{Cr}, \mathrm{Mn}, \mathrm{Zn}$ & Mani and Kumar (2013) \\
\hline & Cladophora sp. and Spirogyra sp. & $\mathrm{Cu}, \mathrm{Pb}$ & Mani and Kumar (2013) \\
\hline & Cladophora fascicularis & $\mathrm{Pb}$ & Mani and Kumar (2013) \\
\hline & Chlorella pyrendoidosa & $\mathrm{U}$ & Mani and Kumar (2013) \\
\hline & $\begin{array}{l}\text { Ascophyllum nodosum, } \\
\text { Chlorella fusca, Aspergillus niger, Bacillus firmus }\end{array}$ & $\begin{array}{l}\mathrm{Ni}, \mathrm{Cd}, \mathrm{Pb}, \mathrm{Zn}, \mathrm{Cu}, \\
\mathrm{Cr},\end{array}$ & Mani and Kumar (2013) \\
\hline
\end{tabular}




\section{System biology and gene editing tool bioremediation studies}

\subsection{Gene editing for "ex situ" bioremediation}

The mechanism of gene editing involves the process of manipulation of DNA with the help of engineered nucleases. The use of nucleases has proven to have immense application in vast areas of researches including animals, plants and microbes (Butt et al., 2018). Studies has shown that the gene editing tools (Figure 3 ) possess the ability to enhance the rate of bioremediation by the mechanism of conversion of toxic compounds to lesser toxic substances, elimination of the xenobiotics, remediation of heavy metals and ability to degrade complex forms of the pesticides (Basu et al., 2018). At present condition the major gene editing tools include ZFN, TALEN and CRISPR-Cas has proven to enhance the mechanism of bioremediation. The mechanism of CRISPR-Cas is one of the most effective mechanisms for the purpose of gene editing comprise of three types and various subtypes (Zhu et al., 2018; Behler et al., 2018). TALEN or Transcription Activator Like Effector Nuclease which also acts as an efficient tool for the purpose of gene editing and helps in enhancing the rate of bioremediation. Another commonly used mechanism of gene editing is Zinc Finger Nucleases or Zinc Finger Proteins (ZFPs) which helps in accurate target gene editing.

\subsection{Biodegradation network for ex situ bioremediation}

Bioinformatics and computational tools are alternate approaches towards the mechanism of bioremediation (Malla et al., 2018; Vanacek et al., 2018). The online database provides a platform (Table 4 ) for the purpose of retrieving

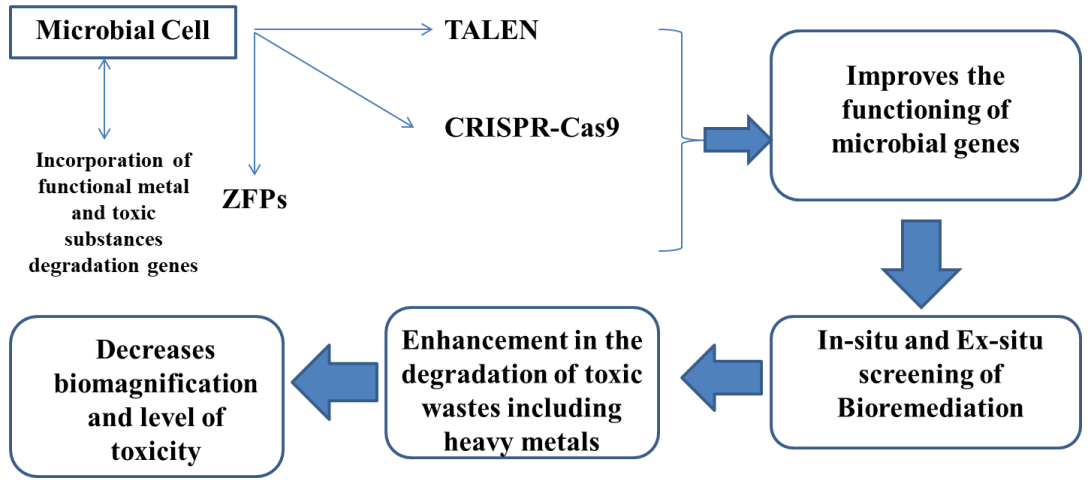

Figure 3. Various types of gene editing tools for bioremediation (TALEN: Transcription Activator Like Effector Nuclease, ZFPs- Zinc Finger Proteins)

Table 4. Computation oriented biodegradation studies

\begin{tabular}{|l|l|l|l|}
\hline \multicolumn{1}{|c|}{$\begin{array}{c}\text { Databases for Understanding } \\
\text { Bioremediations }\end{array}$} & \multicolumn{1}{|c|}{ Links for the Servers } & Utility in the Process of Bioremediation & Reference \\
\hline $\begin{array}{l}\text { The Environmental Contaminant } \\
\text { Biotransformation Pathway } \\
\text { (EAWAGBBD/PPS) }\end{array}$ & https://envipath.org/ & Provides the multi-omics information & $\begin{array}{l}\text { Malla et al. } \\
(2018)\end{array}$ \\
\hline $\begin{array}{l}\text { Microbial Genome Database } \\
\text { (MBGD) }\end{array}$ & http://mbgd.genome/ & $\begin{array}{l}\text { Provides information about comparative aspect on } \\
\text { microbial genome }\end{array}$ & $\begin{array}{l}\text { Fory et al. } \\
(2014)\end{array}$ \\
\hline $\begin{array}{l}\text { Metarouter } \\
\text { http://pdg.cnb.uam.es/ } \\
\text { MetaRouter }\end{array}$ & $\begin{array}{l}\text { It helps in maintaining diverse information related } \\
\text { to biodegradation or bioremediation }\end{array}$ & $\begin{array}{l}\text { Paliwal et al. } \\
(2012)\end{array}$ \\
\hline $\begin{array}{l}\text { Metabolic Pathway Database } \\
\text { (MetaCyc) }\end{array}$ & https://metacyc.org/ & $\begin{array}{l}\text { It helps in assessing the catabolic pathways and } \\
\text { helps in predicting various metabolic pathways }\end{array}$ & $\begin{array}{l}\text { Millacura } \\
\text { et al. (2017) }\end{array}$ \\
\hline $\begin{array}{l}\text { Pathway/Genome Databases } \\
\text { (BioCyc) }\end{array}$ & $\begin{array}{l}\text { https://biocyc.org/ } \\
\text { It provides information regarding the genetics } \\
\text { and biochemistry of toxic waste degradation by } \\
\text { microorganisms }\end{array}$ & $\begin{array}{l}\text { Arora and } \\
\text { Bae (2014) }\end{array}$ \\
\hline $\begin{array}{l}\text { Oxygenase Database (OxDBase) } \\
\text { http://crdd.osdd.net/ } \\
\text { raghava/oxdbase/ }\end{array}$ & $\begin{array}{l}\text { It provides information regarding various types of } \\
\text { oxygenase activities }\end{array}$ & $\begin{array}{l}\text { Arora and } \\
\text { Bae (2014) }\end{array}$ \\
\hline $\begin{array}{l}\text { Biodegradation Network- } \\
\text { Molecular } \\
\text { Biology Database (Bionemo) }\end{array}$ & $\begin{array}{l}\text { http://bionemo.bioinfo.cnio. } \\
\text { es/ }\end{array}$ & $\begin{array}{l}\text { It provides information regarding the regulation } \\
\text { of degradation by metabolic pathways and the } \\
\text { transcriptional factors involved in the mechanism } \\
\text { of degradation }\end{array}$ & $\begin{array}{l}\text { Arora and } \\
\text { Bae (2014) }\end{array}$ \\
\hline $\begin{array}{l}\text { University of Minnesota } \\
\text { Biocatalysis/Biodegradation } \\
\text { Database (UMBBD) }\end{array}$ & $\begin{array}{l}\text { https://www.msi.umn. } \\
\text { edu/content/university- } \\
\text { minnesota-biocatalysis-and- } \\
\text { biodegradation-database }\end{array}$ & $\begin{array}{l}\text { It provides information pertaining to the mecha- } \\
\text { nisms involved in degradation of toxic substances } \\
\text { and the various genes, enzymes and various types } \\
\text { of microbial enzymes involved in the processes }\end{array}$ & $\begin{array}{l}\text { Arora and } \\
\text { Bae (2014) }\end{array}$ \\
\hline
\end{tabular}


information on the mechanism of biodegradation by microorganisms and the pathways that are involved in the mechanism of degrading the toxic chemicals (Nolte et al., 2018). Various databases are involved that provide the information and mechanism of bioremediation of toxic chemicals.

\subsection{Computational tool for assessing "ex situ" bioremediation}

The interactions between the microbes and various chemical compounds can be analyzed with the help of various scientific technologies and system biology approaches. The process of improving the soil health can be analyzed by the integration of various computational methods (De Sousa et al., 2018). Molecular interactions of the microbial enzymes with targeted toxic compounds or heavy metals can be analyzed with the help of in silico approaches (Malla et al., 2018). Computational Biology help in understanding the in silico approaches of proteins and genes by considering a cellular system (Purohit et al., 2018). The in silico technique provides the concept of various metabolic pathways that are involved in the mechanism of bioremediation of toxic metals (Liu et al., 2018). This technique also helps in the mechanism of data mining by understanding the knowledge on various mechanisms involved in the metabolic network for the enhancement of cellular processes involving the mechanism of bioremediation (Ostrem Loss $\& \mathrm{Yu}, 2018)$. The stoichiometric analysis of metabolic network can be analyzed by the determination of metabolic flux analysis (MFA), flux balance analysis (FBA) and metabolic pathway analysis (MPA) (Zhang \& Xiu, 2009).

\subsection{Multi-omics approach}

The utility of computational application in the field of biological sciences help in understanding the interactions of various proteins encoded by genes with a cellular model or the model developed by organisms (Figure 4). Hence provides a suitable platform in studying the metabolic processes involved in biodegradation or bioremediations. The field of Genomics helps in studying various molecular level genetics approaches (Jaiswal et al., 2019).

\section{Conclusions and future prospects}

This review categorically depicted the scientific progress and various applications of the biotechnological tools for environmental management and its implication in the process of bioremediation to protect the environment and mitigate hazardous heavy metals. Various environmental problems are to be seriously analyzed and properly addressed to prevent environmental degradation. The mechanism also involved the multi-faceted use of systems biology and computational techniques for determining the mode of degradation and various types of interactions that are involved. There are various types of approaches like the use of microbial induced calcite precipitation by the involvement of the urease hydrolyzing bacteria, development of nanoparticles and the use of biosensors in the detection of remediation of toxic metals from the environment. Another important mechanism addressed is genetic modification for developing microbes possessing greater efficacies in degradation of various heavy metals being present within the environment. The future prospects of the remediation techniques include the adoption of better strategies by the policymakers and implementation of highly advanced techniques by the bioremediation practitioners under the surveillance of the environmentalists to clean up the toxic heavy metals from the environment to make it more habitable for our future generations.

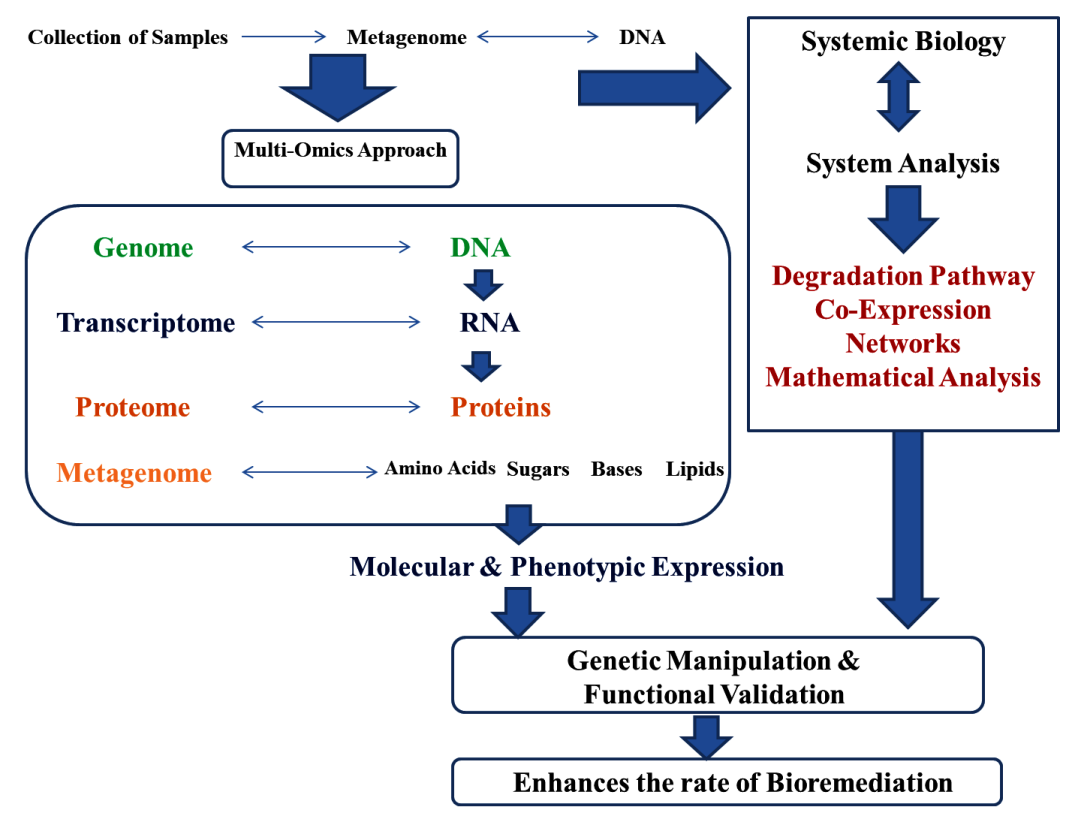

Figure 4. Multi-omics approach for improving bioremediation 


\section{Funding}

The authors wish to acknowledge Department of Biotechnology, Govt of West Bengal for financial assistance.

\section{Authors' contributions}

All the authors contributed equally.

\section{References}

Achal, V., Pan, X., \& Zhang, D. (2011). Remediation of coppercontaminated soil by Kocuria flava CR1, based on microbially induced calcite precipitation. Ecological Engineering, 37(10), 1601-1605. https://doi.org/10.1016/j.ecoleng.2011.06.008

Achiba, W. B., Gabteni, N., Lakhdar, A., Laing, G. D., Verloo, M., Jedidi, N., \& Gallali, T. (2009). Effects of 5-year application of municipal solid waste compost on the distribution and mobility of heavy metals in a Tunisian calcareous soil. Agriculture, Ecosystems \& Environment, 130(3-4), 156-163. https://doi.org/10.1016/j.agee.2009.01.001

Adams, J. A., \& Reddy, K. R. (2003). Extent of benzene biodegradation in saturated soil column during air sparging. Ground Water Monitoring Remediation, 23(3), 85-94. https://doi.org/10.1111/j.1745-6592.2003.tb00686.x

Aftab, B., Khan, S. J., Maqbool, T., \& Hankins, N. P. (2017). Heavy metals removal by osmotic membrane bioreactor (OMBR) and their effect on sludge properties. Desalination, 403, 117-127. https://doi.org/10.1016/j.desal.2016.07.003

Al-Sulaimani, H. S., Al-Wahaibi, Y. M., Al-Bahry, S., Elshafie, A., Al-Bemani, A. S., Joshi, S. J., \& Zargari, S. (2010). Experimental investigation of biosurfactants produced by Bacillus species and their potential for MEOR in Omani oil field. In Proceedings of the SPE EOR Conference at Oil and Gas West Asia 2010 (OGWA 10) (pp. 378-386), Muscat, Oman. Society of Petroleum Engineers. https://doi.org/10.2118/129228-MS

Anjum, M., Miandad, R., Waqas, M., Gehany, F., \& Barakat, M. A. (2016). Remediation of wastewater using various nanomaterials. Arabian Journal of Chemistry, 12(8), 4897-4919. https://doi.org/10.1016/j.arabjc.2016.10.004

Arora, P. K., \& Bae, H. (2014). Integration of bioinformatics to biodegradation. Biological Procedures Online, 16, 8. https://doi.org/10.1186/1480-9222-16-8

Atagana, H. I. (2008). Compost bioremediation of hydrocarboncontaminated soil inoculated with organic manure. African Journal of Biotechnology, 7(10), 1516-1525.

Aydinalp, C., \& Marinova, S. (2009). The effects of heavy metals on seed germination and plant growth on alfalfa plant (Medicago sativa). Bulgarian Journal of Agricultural Sciences, 15(4), $347-350$.

Azubuike, C. C., Chikere, C. B., \& Okpokwasili, G. C. (2016). Bioremediation techniques-classification based on site of application: principles, advantages, limitations and prospects. World Journal of Microbiology \& Biotechnology, 32(11), 180. https://doi.org/10.1007/s11274-016-2137-x

Baker, R. S., \& Moore, A. T. (2000). Optimizing the effectiveness of in situ bioventing. Pollution Engineering, 32(7), 44-47.

Bandowe, B. A. M., Bigalke, M., Boamah, L., Nyarko, E., Saalia, F. K., \& Wilcke, W. (2014). Polycyclic aromatic compounds (PAHs and oxygenated PAHs) and trace metals in fish species from Ghana (West Africa): Bioaccumulation and health risk assessment. Environmental International, 65, 135146. https://doi.org/10.1016/j.envint.2013.12.018
Bandowe, B. A. M., \& Meusel, H. (2017). Nitrated polycyclic aromatic hydrocarbons (nitro-PAHs) in the environment a review. Science of Total Environmental, 581-582, 237-257. https://doi.org/10.1016/j.scitotenv.2016.12.115

Barros, A. J. M., Prasad, S., Leite, V. D., \& Souza, A. G. (2006). The process of biosorption of heavy metals in bioreactors loaded with sanitary sewage sludge. Brazilian Journal of Chemical Engineering, 23(2), 153-162. https://doi.org/10.1590/S0104-66322006000200001

Basu, S., Rabara, R. C., Negi, S., \& Shukla, P. (2018). Engineering PGPMOs through gene editing and systems biology: A solution for phytoremediation? Trends in Biotechnology, 36, 499-510. https://doi.org/10.1016/j.tibtech.2018.01.011

Behler, J., Sharma, K., Reimann, V., Wilde, A., Urlaub, H., \& Hess, W. R. (2018). The host-encoded RNase E endonuclease as the crRNA maturation enzyme in a CRISPR-Cas subtype III-Bv system. Nature Microbiology, 3(3), 367-377. https://doi.org/10.1038/s41564-017-0103-5

Bento, F. M., Camargo, F. A., Okeke, B. C., \& Frankenberger, W. T. (2005). Comparative bioremediation of soils contaminated with diesel oil by natural attenuation, biostimulation and bioaugmentation. Bioresourource Technology, 96(9), 1049-1055. https://doi.org/10.1016/j.biortech.2004.09.008

Boopathy, R. (2000). Factors limiting bioremediation technologies. Bioresource Technology, 74(1), 63-67. https://doi.org/10.1016/S0960-8524(99)00144-3

Bundy, J. G., Paton, G. I., \& Campbell, C. D. (2002). Microbial communities in different soil types do not converge after diesel contamination. Journal of Applied Microbiology, 92(2), 276-288. https://doi.org/10.1046/j.1365-2672.2002.01528.x

Butt, H., Jamil, M., Wang, J. Y., Al-Babili, S., \& Mahfouz, M. M. (2018). Engineering plant architecture via CRISPR/Cas9-mediated alteration of strigolactone biosynthesis. BMC Plant Biology, 18(1), 174. https://doi.org/10.1186/s12870-018-1387-1

Carberry, B. J., \& Wik, J. (2001). Comparison of ex situ and 'in situ' bioremediation of unsaturated soils contaminated by petroleum. Journal of Environmental Science and Health, Part A, 36(8), 1491-1503. https://doi.org/10.1081/ESE-100105726

Cervantes, C., Campos-García, J., Devars, S., Gutiérrez-Corona, F., Loza-Tavera, H., Torres-Guzmán, J. C., \& MorenoSánchez, R. (2001). Interactions of chromium with microorganisms and plants. FEMS Microbiology Reviews, 25(3), 335-347. https://doi.org/10.1111/j.1574-6976.2001.tb00581.x

Chemlal, R., Abdi, N., Lounici, H., Drouiche, N., Pauss, A., \& Mameri, N. (2013). Modeling and qualitative study of diesel biodegradation using biopile process in sandy soil. International Biodeterioration and Biodegradation, 78, 43-48. https://doi.org/10.1016/j.ibiod.2012.12.014

Choudhary, S., \& Sar, P. (2011). Uranium biomineralization by a metal resistant Pseudomonas aeruginosa strain isolated from contaminated mine waste. Journal of Hazardous Materials, 186(1), 336-343.

https://doi.org/10.1016/j.jhazmat.2010.11.004

Dary, M., Chamber-Pérez, M. A., Palomares, A. J., \& Pajuelo, E. (2010). "In situ" phytostabilisation of heavy metal polluted soils using Lupinus luteus inoculated with metal resistant plant-growth promoting rhizobacteria. Journal of Hazardous Materials, 177(1-3), 323-330. https://doi.org/10.1016/j.jhazmat.2009.12.035

Dash, H. R., \& Das, S. (2012). Bioremediation of mercury and the importance of bacterial mer genes. International Biodeterioration \& Biodegradation, 75, 207-213. https://doi.org/10.1016/j.ibiod.2012.07.023 
Davis, C. M., \& Vincent, J. B. (1997). Chromium oligopeptide activates insulin receptor tyrosine kinase activity. Biochemistry, 36(15), 4382-4385. https://doi.org/10.1021/bi963154t

Davis, J. W., Klier, N. J., \& Carpenter, C. L. (1994). Natural biological attenuation of benzene in ground water beneath a manufacturing facility. Groundwater, 32(2), 215-226. https://doi.org/10.1111/j.1745-6584.1994.tb00636.x

De Pourcq, K., Ayora, C., García-Gutiérrez, M., Missana, T., \& Carrera, J. (2015). A clay permeable reactive barrier to remove Cs-137 from groundwater: Column experiments. Journal of Environmental Radioactivity, 149, 36-42. https://doi.org/10.1016/j.jenvrad.2015.06.029

De Sousa, C. S., Hassan, S. S., Pinto, A. C., Silva, W. M., De Almeida, S. S., \& Soares, S. D. C. (2018). Microbial omics: Applications in biotechnology. In D. Barh \& V. Azevedo (Eds.), Omics technologies and bio-engineering (pp. 3-20). Academic Press. https://doi.org/10.1016/B978-0-12-815870-8.00001-2

de-Bashan, L. E., Hernandex, J.-P., \& Bashan, Y. (2012). The potential contribution of plant growth-promoting bacteria to reduce environmental degradation - A comprehensive evaluation. Applied Soil Ecology, 61, 171-189. https://doi.org/10.1016/j.apsoil.2011.09.003

Delille, D., Duval, A., \& Pelletier, E. (2008). Highly efficient pilot biopiles for on-site fertilization treatment of diesel oilcontaminated sub-Antarctic soil. Cold Regions Science and Technology, 54, 7-18. https://doi.org/10.1016/j.coldregions.2007.09.003

Deng, L., Su, Y., Su, H., Wang, X., \& Zhu, X. (2007). Sorption and desorption of lead (II) from wastewater by green algae Cladophora fascicularis. Journals of Hazardous Materials, 143(1-2), 220-225.

https://doi.org/10.1016/j.jhazmat.2006.09.009

Dimkpa, C. O., Merten, D., Svatoš, A., Büchel, G., \& Kothe, E. (2009). Siderophores mediate reduced and increased uptake of cadmium byStreptomyces tendaeF4 and sunflower (Helianthus annuus), respectively. Journal of Applied Microbiology, 107(5), 1687-1696.

https://doi.org/10.1111/j.1365-2672.2009.04355.x

Di Toro, S., Zanaroli, G., \& Fava, F. (2006). Intensification of the aerobic bioremediation of an actual site soil historically contaminated by polychlorinated biphenyls (PCBs) through bioaugmentation with a non acclimated, complex source of microorganisms. Microbial Cell Factories, 5, 11.

Dong, G., Wang, Y., Gong, L., Wang, M., Wang, H., He, N., \& Li, Q. (2013). Formation of soluble Cr(III) end-products and nanoparticles during $\mathrm{Cr}(\mathrm{VI})$ reduction by Bacillus cereus strain XMCr-6. Biochemical Engineering Journal, 70, 166172. https://doi.org/10.1016/j.bej.2012.11.002

Fauziah, S. H., Jayanthi, B., Emenike, C. U., \& Agamuthu. (2017). Remediation of heavy metal contaminated soil using potential microbes isolated from a closed disposal site. International Journal of Bioscience, Biochemistry and Bioinformatics, 7(4), 230-237. https://doi.org/10.17706/ijbbb.2017.7.4.230-237

Folch, A., Vilaplana, M., Amado, L., Vicent, T., \& Caminal, G. (2013). Fungal permeable reactive barrier to remediate groundwater in an artificial aquifer. Journal of Hazardous Materials, 262, 554-560. https://doi.org/10.1016/j.jhazmat.2013.09.004

Fory, P. A., Triplett, L., Ballen, C., Abello, J. F., Duitama, J., \& Aricapa, M. G. (2014). Comparative analysis of two emerging rice seed bacterial pathogens. Phytopathology, 104(5), 436-444. https://doi.org/10.1094/PHYTO-07-13-0186-R

Francis, A. J. (1990). Microbial dissolution and stabilization of toxic metals and radionuclides in mixed wastes. Experientia, 46, 840-851. https://doi.org/10.1007/BF01935535
Frascari, D., Zanaroli, G., \& Danko, A. S. (2015). 'In situ' aerobic cometabolism of chlorinated solvents: A review. Journal of Hazardous Materials, 283, 382-399.

https://doi.org/10.1016/j.jhazmat.2014.09.041

Fruchter, R., \& Demian, P. (2002). CoMem: Designing an interaction experience for reuse of rich contextual knowledge from a corporate memory. AI EDAM, 16(3), 127-147.

https://doi.org/10.1017/S0890060402163025

Frutos, F. J. G., Pérez, R., Escolano, O., Rubio, A., Gimeno, A., Fernandez, M. D., Carbonell, G., Perucha, C., \& Laguna, J. (2012). Remediation trials for hydrocarbon-contaminated sludge from a soil washing process: Evaluation of bioremediation technologies. Journal of Hazardous Materials, 199, 262-271. https://doi.org/10.1016/j.jhazmat.2011.11.017

Fulekar, M. H., Sharma, J., \& Tendulkar, A. (2012). Bioremediation of heavy metals using biostimulation in laboratory bioreactor. Environmental Monitoring and Assessments, 184(12), 7299-7307. https://doi.org/10.1007/s10661-011-2499-3

Garbisu, C., Alkorta, I., Llama, M. J., \& Serra, J. L. (1998). Aerobic chromate reduction by bacillus subtilis. Biodegradation, 9, 133-141. https://doi.org/10.1023/A:1008358816529

García, Y., Ruiz, C., Mena Ramírez, E., Villaseñor Camacho, J., Cañizares, P., \& Rodrigo, M. A. (2014). Removal of nitrates from spiked clay soils by coupling electrokinetic and permeable reactive barrier technologies. Journal of Chemical Technology and Biotechnology, 90, 1719-1726.

Gibert, O., Cortina, J. L., de Pablo, J., \& Ayora, C. (2013). Performance of a field-scale permeable reactive barrier based on organic substrate and zero-valent iron for in situ remediation of acid mine drainage. Environmental Science and Pollution Research, 20(11), 7854-7862.

https://doi.org/10.1007/s11356-013-1507-2

Gidarakos, E., \& Aivalioti, M. (2007). Large scale and long term application of bioslurping: The case of a Greek petroleum refinery site. Journal of Hazardous Materials, 149, 574-581. https://doi.org/10.1016/j.jhazmat.2007.06.110

Godwill, E. A., Ferdinand, P. U., Nwalo, F. N., \& Unachukwu, M. N. (2019). Mechanism and health effects of heavy metal toxicity in humans. In Poisoning in the modern worldnew tricks for an old dog? IntechOpen. https://doi.org/10.5772/intechopen.82511

González-Chávez, M. C., Carrillo-González, R., Wright, S. F., \& Nichols, K. A. (2004). The role of glomalin, a protein produced by arbuscular mycorrhizal fungi, in sequestering potentially toxic elements. Environmental Pollution, 130(3), 317-323. https://doi.org/10.1016/j.envpol.2004.01.004

Guo, H., Luo, S., Chen, L., Xiao, X., Xi, Q., Wei, W., Zeng, G., Liu, C., Wan, Y., Chen, J., \& He, Y. (2010). Bioremediation of heavy metals by growing hyperaccumulator endophytic bacterium Bacillus sp. L14. Bioresource Technology, 101(22), 8599-8605. https://doi.org/10.1016/j.biortech.2010.06.085

Hattab, N., Hambli, R., Motelica-Heino, M., \& Bourrat, X. (2013). Application of neural network model for the prediction of Chromium concentration in phytoremediated contaminated soils. Journal of Geochemical Exploration, 128, 25-34. https://doi.org/10.1016/j.gexplo.2013.01.005

Henderson, A. D., \& Demond, A. H. (2013). Pemeability of iron sulfide (FeS)-based materials for groundwater remediation. Water Research, 47, 1267-1276. https://doi.org/10.1016/j.watres.2012.11.044

Hildebrandt, U., Regvar, M., \& Bothe, H. (2007). Arbuscular mycorrhiza and heavy metal tolerance. Phytochemistry, 68, 139-146. https://doi.org/10.1016/j.phytochem.2006.09.023 
Hobson, A. M., Frederickson, J., \& Dise, N. B. (2005). $\mathrm{CH}_{4}$ and $\mathrm{N}_{2} \mathrm{O}$ from mechanically turned windrow and vermicomposting systems following in-vessel pre-treatment. Waste Management, 25, 345-352.

https://doi.org/10.1016/j.wasman.2005.02.015

Hopkins, W. A., Congdon, J., \& Ray, J. K. (2000). Incidence and impact of axial malformations in larval bullfrogs (Rana catesbeiana) developing in sites polluted by a coal-burning power plant. Environmental Toxicology and Chemistry, 19(4), 862-868. https://doi.org/10.1002/etc.5620190412

Hrynkiewicz, K., Dabrowska, G., Baum, C., Niedojadlo, K., \& Leinweber, P. (2012). Interactive and single effects of ectomycorrhiza formation and Bacillus cereus on metallothionein MT1 expression and phytoextraction of Cd and Zn by Willows. Water, Air, and Soil Pollution, 223, 957-968. https://doi.org/10.1007/s11270-011-0915-5

Huang, T., Li, D., \& Kexiang, L. (2015). Heavy metal removal from MSWI fly ash by electrokinetic remediation coupled with a permeable activated charcoal reactive barrier. Scientific Reports, 5, 15412. https://doi.org/10.1038/srep15412

Ibrahim, A. E. D. M., Hamdona, S., \& El-Naggar, M. (2019). Heavy metal removal using a fixed bed bioreactor packed with a solid supporter. Beni-Suef University Journal of Basic and Applied Sciences, 8, 1. https://doi.org/10.1186/s43088-019-0002-3

Ijaz, A., Shabir, G., Khan, Q. M., \& Afzal, M. (2015). Enhanced remediation of sewage effluent by endophyte-assisted floating treatment wetlands. Ecological Engineering, 84, 58-66. https://doi.org/10.1016/j.ecoleng.2015.07.025

Ismail, T. N. H. T., Adon, R. A. M., Diman, S. F., \& Wijeyesekera, D. C. (2013). Innovative green technology and products meeting geo-environmental challenges. Procedia Engineering, 53, 104-115. https://doi.org/10.1016/j.proeng.2013.02.016

Jaiswal, S., Singh, D. K., \& Shukla, P. (2019). Gene editing and systems biology tools for pesticide bioremediation: A review. Frontiers in Microbiology, 10, 87.

https://doi.org/10.3389/fmicb.2019.00087

Jeyasingh, J., \& Philip, L. (2005). Bioremediation of Chromium contaminated soil: Optimization of operating parameters under laboratory conditions. Journal of Hazardous Materials, $118(1-3), 113-120$. https://doi.org/10.1016/j.jhazmat.2004.10.003

Jiang, C.-Y., Sheng, X.-F., Qian, M., \& Wang, Q.-Y. (2008). Isolation and characterization of heavy metal resistant Burkholderia species from heavy metal contaminated paddy field soil and its potential in promoting plant growth and heavy metal accumulation in metal polluted soil. Chemosphere, 72, 157-164. https://doi.org/10.1016/j.chemosphere.2008.02.006

Jørgensen, K. S. (2007). In situ bioremediation. Advances in Applied Microbiology, 61, 285-305.

https://doi.org/10.1016/S0065-2164(06)61008-3

Joshi, P. M., \& Juwarkar, A. A. (2009). In vivo studies to elucidate the role of extracellular polymeric substances from Azotobacter in immobilization of heavy metals. Environmental Science and Technology, 43(15), 5884-5889.

https://doi.org/10.1021/es900063b

Kanmani, P., Aravind, J., \& Preston, D. (2012). Remediation of chromium contaminants using bacteria. International Journal of Environmental Science and Technology, 9, 183-193. https://doi.org/10.1007/s13762-011-0013-7

Kapahi, M., \& Sachdeva, S. (2019). Bioremediation options for heavy metal pollution. Journal of Health and Pollution, 9(24), 191-203. https://doi.org/10.5696/2156-9614-9.24.191203

Kardam, A., Raj, K., \& Srivastava, S. (2012). Green nanotechnology for bioremediation of toxic metals from waste water. In
L. Khemani, M. Srivastava, \& S. Srivastava (Eds.), Chemistry of phytopotentials: Health, energy and environmental perspectives. Springer.

Katsou, E., Malamis, S., \& Loizidou, M. (2011). Performance of a membrane bioreactor used for the treatment of wastewater contaminated with heavy metals. Bioresource Technology, 102(6), 4325-4332.

https://doi.org/10.1016/j.biortech.2010.10.118

Khan, F. I., Tahir, H., \& Ramzi, H. (2004). An overview and analysis of site remediation technologies. Journal of Environmental Management, 71, 95-122.

https://doi.org/10.1016/j.jenvman.2004.02.003

Kim, S., Choi, D., Sim, D., \& Oh, Y. (2005). Evaluation of bioremediation effectiveness on crude oil-contaminated sand. Chemosphere, 59(6), 845-852. https://doi.org/10.1016/j.chemosphere.2004.10.058

Kim, S., Krajmalnik-Brown, R., Kim, J.-O., \& Chung, J. (2014). Remediation of petroleum hydrocarbon-contaminated sites by DNA diagnosis-based bioslurping technology. Science of The Total Environment, 497-498, 250-259.

https://doi.org/10.1016/j.scitotenv.2014.08.002

Komesli, O. T. (2014). Removal of heavy metals in wastewater by membrane bioreactor: Effects of flux and suction period. Journal of the Chemical Society of Pakistan, 36(4), 654.

Kumari, B., \& Singh, S. N. (2011). Phytoremediation of metals from fly ash through bacterial augmentation. Ecotoxicology, 20, 166-176. https://doi.org/10.1007/s10646-010-0568-y

Latha, P. A., \& Reddy, S. S. (2013). Review on bioremediation potential tool for removing environmental pollution. International Journal of Basic and Applied Chemical Sciences.

Lauwerys, R., Haufroid, V., Hoet, P., \& Lison, D. (2007). Toxicologie industrielle et intoxications professionnelles. Elsevier.

Lebeau, T., \& Jézéquel, K. (2008). Performance of bioaugmentation-assisted phytoextraction applied to metal contaminated soils: A review. Environmental Pollution, 153(3), 497-522. https://doi.org/10.1016/j.envpol.2007.09.015

Lee, J. H. (2013). An overview of phytoremediation as a potentially promising technology for environmental pollution control. Biotechnology and Bioprocess Engineering, 18, 431-439. https://doi.org/10.1007/s12257-013-0193-8

LeFauve, M. K., \& Connaughtont, V. P. (2017). Developmental exposure to heavy metals alters visually-guided behaviors in zebrafish. Current Zoology, 63(2), 221-227.

https://doi.org/10.1093/cz/zox017

Liu, Z., Liu, Y., Zeng, G., Shao, B., Chen, M., \& Li, Z. (2018). Application of molecular docking for the degradation of organic pollutants in the environmental remediation: A review. Chemosphere, 203, 139-150.

https://doi.org/10.1016/j.chemosphere.2018.03.179

Loukidou, M. X., Matis, K. A., Zouboulis, A. I., \& LiakopoulouKyriakidou, M. (2003). Removal of As(V) from wastewaters by chemically modified fungal biomass. Water Research, 37(18), 4544-4552. https://doi.org/10.1016/S0043-1354(03)00415-9

Magalhães, S. M. C., Ferreira, J. R. M., \& Castro, P. M. L. (2009). Investigations into the application of a combination of bioventing and biotrickling filter technologies for soil decontamination processes - A transition regime between bioventing and soil vapour extraction. Journal of Hazardous Materials, 170, 711-715. https://doi.org/10.1016/j.jhazmat.2009.05.008

Maila, M. P., \& Cloete, T. E. (2004). Bioremediation of petroleum hydrocarbons through landfarming: Are simplicity and costeffectiveness the only advantages? Reviews in Environmental Science and Bio/Technology, 3, 349-360. 
Malla, M. A., Dubey, A., Yadav, S., Kumar, A., Hashem, A., \& Abd_Allah, E. F. (2018). Understanding and designing the strategies for the microbe-mediated remediation of environmental contaminants using omics approaches. Frontiers in $\mathrm{Mi}$ crobiology, 9, 1132. https://doi.org/10.3389/fmicb.2018.01132

Manahan, S. (2010). Environmental chemistry. CRC Press.

Mani, D., \& Kumar, C. (2013). Biotechnological advances in bioremediation of heavy metals contaminated ecosystems: An overview with special reference to phytoremediation. International Journal of Environmental Science and Technology, 11(3), 843-872. https://doi.org/10.1007/s13762-013-0299-8

Manisalidis, I., Stavropoulou, E., Stavropoulos, A., \& Bezirtzoglou, E. (2020). Environmental and health impacts of air pollution: A review. Frontiers in Public Health, 8, 14. https://doi.org/10.3389/fpubh.2020.00014

Martin, S., \& Griswold, W. (2009). Human health effects of heavy metals. Environmental Science and Technology Briefs for Citizens, 15, 1-6.

Meagher, R. B. (2000). Phytoremediation of toxic elemental and organic pollutants. Current Opinion in Plant Biology, 3, 153162. https://doi.org/10.1016/S1369-5266(99)00054-0

Mena, E., Ruiz, C., Villaseñor, J., Rodrigo, M. A., \& Cañizares, P. (2015). Biological permeable reactive barriers coupled with electrokinetic soil flushing for the treatment of diesel-polluted clay soil. Journal of Hazardous Materials, 283, 131-139. https://doi.org/10.1016/j.jhazmat.2014.08.069

Mench, M., Schwitzguébel, J.-P., Schroeder, P., Bert, V., Gawronski, S., \& Gupta, S. (2009). Assessment of successful experiments and limitations of phytotechnologies: Contaminant uptake, detoxification and sequestration, and consequences for food safety. Environmental Science and Pollution Research, 16, 876-900. https://doi.org/10.1007/s11356-009-0252-z

Millacura, F. A., Cárdenas, F., Mendez, V., Seeger, M., \& Rojas, L. A. (2017). Degradation of benzene by the heavy-metal resistant bacterium Cupriavidus metallidurans $\mathrm{CH} 34$ reveals its catabolic potential for aromatic compounds. bioRxiv. https://doi.org/10.1101/164517

Miransari, M. (2013). Soil microbes and the availability of soil nutrients. Acta Physiologiae Plantarum, 35, 3075-3084. https://doi.org/10.1007/s11738-013-1338-2

Mulligan, C. N., \& Yong, R. N. (2004). Natural attenuation of contaminated soils. Enviornment International, 30(4), 587601. https://doi.org/10.1016/j.envint.2003.11.001

Nikolopoulou, M., Pasadakis, N., Norf, H., \& Kalogerakis, N. (2013). Enhanced ex situ bioremediation of crude oil contaminated beach sand by supplementation with nutrients and rhamnolipids. Marine Pollution Bulletin, 77, 37-44. https://doi.org/10.1016/j.marpolbul.2013.10.038

Nolte, T. M., Pinto-Gil, K., Hendriks, A. J., Ragas, A. M., \& Pastor, M. (2018). Quantitative structure-activity relationships for primary aerobic biodegradation of organic chemicals in pristine surface waters: Starting points for predicting biodegradation under acclimatization. Environmental Science: Processes and Impacts, 20, 157-170.

https://doi.org/10.1039/C7EM00375G

Norström, A., Larsdotter, K., Gumaelius, L., Jansen, J. L. C., \& Dalhammar, G. (2004). A small scale hydroponics wastewater treatment system under Swedish conditions. Water Science \& Technology, 48(11-12), 161-167. https://doi.org/10.2166/wst.2004.0830

Obiri-Nyarko, F., Grajales-Mesa, S. J., \& Grzegorz, M. (2014) An overview of permeable reactive barriers for in situ sustainable groundwater remediation. Chemosphere, 111, 243-259. https://doi.org/10.1016/j.chemosphere.2014.03.112
Olaniran, A. O., Balgobind, A., \& Pillay, B. (2013). Bioavailability of heavy metals in soil: Impact on microbial biodegradation of organic compounds and possible improvement strategies. International Journal of Molecular Sciences, 14, 10197-10228. https://doi.org/10.3390/ijms140510197

Ostrem Loss, E. M., \& Yu, J.-H. (2018). Bioremediation and microbial metabolism of benzo(a)pyrene. Molecular Microbiology, 109(4), 433-444. https://doi.org/10.1111/mmi.14062

Paliwal, V., Puranik, S., \& Purohit, H. J. (2012). Integrated perspective for effective bioremediation. Applied Biochemistry and Biotechnology, 166, 903-924.

https://doi.org/10.1007/s12010-011-9479-5

Patrick, H., \& Violaine, P. (2014). In situ vadose zone bioremediation. Current Opinion in Biotechnology, 27, 1-7.

https://doi.org/10.1016/j.copbio.2013.08.018

Pazirandeh, M., Wells, B. M., \& Ryan, R. L. (1998). Development of bacterium-based heavy metal biosorbents: Enhanced uptake of cadmium and mercury by escherichia coli expressing a metal binding motif. Applied and Environmental Microbiology, 64, 4068-4072.

https://doi.org/10.1128/AEM.64.10.4068-4072.1998

Peitzsch, N., Eberz, G., \& Nies, D. H. (1998). Alcaligenes eutrophus as a bacterial chromate sensor. Applied and Environmental Microbiology, 64, 453-458.

https://doi.org/10.1128/AEM.64.2.453-458.1998

Pettine, M., Barra, L., Campanella, L., \& Millero, F. J. (1998). Effect of metals on the reduction of Chromium (VI) with hydrogen sulfide. Water Research, 32(9), 2807- 2813.

https://doi.org/10.1016/S0043-1354(98)00011-6

Philp, J. C., \& Atlas, R. M. (2005). Bioremediation of contaminated soils and aquifers. In Bioremediation: Applied microbial solutions for real-world environmental cleanup. American Society for Microbiology.

Pinto, E., Sigaud-kutner, T. C. S., Leitão, M. A. S., Okamoto, O. K., Morse, D., \& Colepicolo, P. (2003). Heavy metal-induced oxidative stress in algae. Journal of Phycology, 39(6), 1008-1018. https://doi.org/10.1111/j.0022-3646.2003.02-193.x

Poey, J., \& Philibert, C. (2000). Toxicité des métaux. Revue Française de Laboratoires, 323, 35-43. https://doi.org/10.1016/S0338-9898(00)80266-8

Purohit, H. J., Tikariha, H., \& Kalia, V. C. (2018). Current scenario on application of computational tools in biological systems. In H. J. Purohit, V. C. Kalia, \& M. R. Prabhakar (Eds.), Soft computing for biological systems (pp. 1-12). Springer. https://doi.org/10.1007/978-981-10-7455-4_1

Rajendran, P., Muthukrishnan, J., \& Gunasekaran, P. (2003). Microbes in heavy metal remediation. Indian Journal of Experimental Biology, 41(9), 935-944.

Rasmussen, L. D., Sørensen, S. J., Turner, R. R., \& Barkay, T. (2000). Application of mer-lux biosensor for estimating bioavailable mercury in soil. Soil Biology and Biochemistry, 32, 639-646. https://doi.org/10.1016/S0038-0717(99)00190-X

Ray, R. R. (2015). Haemotoxic effect of lead: A review. Proceedings of the Zoological Society, 69(2), 161-172. https://doi.org/10.1007/s12595-015-0160-9

Ray, R. R. (2016). Adverse hematological effects of hexavalent chromium: An overview. Interdisciplinary Toxicology, 9(2), 55-65. https://doi.org/10.1515/intox-2016-0007

Rivera, A. L. (1983). Heavy metal removal in a packed-bed, anaerobic upflow (ANFLOW) bioreactor. Water Pollution Control Federation, 55(12), 1450-1456.

Robles-González, I. V., Fava, F., \& Poggi-Varaldo, H. M. (2008). A review on slurry bioreactors for bioremediation of soils and sediments. Microbial Cell Factories, 7, 5. https://doi.org/10.1186/1475-2859-7-5 
Roy, M., Giri, A. K., Dutta, S., \& Mukherjee, P. (2015). Integrated phytobial remediation for sustainable management of arsenic in soil and water.Environment International, 75, 180-198. https://doi.org/10.1016/j.envint.2014.11.010

San Miguel, A., Ravanel, P., \& Raveton, M. (2013). A comparative study on the uptake and translocation of organochlorines by Phragmites australis. Journal of Hazardous Materials, 244, 60-69. https://doi.org/10.1016/j.jhazmat.2012.11.025

Saravanan, V. S., Madhaiyan, M., \& Thangaraju, M. (2007). Solubilization of zinc compounds by the diazotrophic, plant growth promoting bacterium Gluconacetobacter diazotrophicus. Chemosphere, 66(9), 1794-1798.

https://doi.org/10.1016/j.chemosphere.2006.07.067

Say, R., Yimaz, N., \& Denizli, A. (2003). Removal of heavy metal ions using the fungus Penicillium canescens. Adsorption Science and Technology, 21, 643-650.

https://doi.org/10.1260/026361703772776420

Schmidt, A., Haferburg, G., Sineriz, M., Merten, D., Büchel, G., \& Kothe, E. (2005). Heavy metal resistance mechanisms in actinobacteria for survival in AMD contaminated soils. Geocheminstry, 65(S1), 131-144.

https://doi.org/10.1016/j.chemer.2005.06.006

Seigle-Murandi, F., Guiraud, P., Croize, J., Falsen, E., \& Eriksson, K. L. (1996). Bacteria are omnipresent on phanerochaete chrysosporium burdsall. Applied and Environmental Microbiology, 62(7), 2477-2481.

https://doi.org/10.1128/aem.62.7.2477-2481.1996

Shazia, I., Uzma, Sadia, G. R., \& Talat, A. (2013). Bioremediation of heavy metals using isolates of filamentous fungus aspergillus fumigatus collected from polluted soil of Kasur, Pakistan. International Research Journal of Biological Sciences, 2(12), 66-73.

Silva-Castro, G. A., Uad, I., Rodríguez-Calvo, A., GonzálezLópez, J., \& Calvo, C. (2015). Response of autochthonous microbiota of diesel polluted soils to land-farming treatments. Environmental Research, 137, 49-58. https://doi.org/10.1016/j.envres.2014.11.009

Smets, B. F., \& Pritchard, P. H. (2003). Elucidating the microbial component of natural attenuation. Current Opinion in Biotechnology, 14, 283. https://doi.org/10.1016/S0958-1669(03)00062-4

Smith, E., Thavamani, P., Ramadass, K., Naidu, R., Srivastava, P., \& Megharaj, M. (2015). Remediation trials for hydrocarboncontaminated soils in arid environments: Evaluation of bioslurry and biopiling techniques. International Biodeterioration \& Biodegradation, 101, 56-65.

https://doi.org/10.1016/j.ibiod.2015.03.029

Stamets, P. (2005). Mycelium running: how mushrooms can help save the world. Ten Speed Press.

Tampouris, S., Papassiopi, N., \& Paspaliaris, I. (2001). Removal of contaminant metals from fine grained soils, using agglomeration, chloride solutions and pile leaching techniques. Journal of Hazardous Material, 84(2-3), 297-319.

https://doi.org/10.1016/S0304-3894(01)00233-3

Taştan, B. E., Ertuğrul, S., \& Dönmez, G. (2010). Effective bioremoval of reactive dye and heavy metals by Aspergillus versicolor. Bioresource Technology, 101(3), 870-876. https://doi.org/10.1016/j.biortech.2009.08.099

Thiruvenkatachari, R., Vigneswaran, S., \& Naidu, R. (2008). Permeable reactive barrier for groundwater remediation. Journal of Industrial and Engineering Chemistry, 14, 145-156.

Tiecher, T. L., Ceretta, C. A., Ferreira, P. A. A., Lourenzi, C. R., Tiecher, T., Girotto, E., Nicoloso, F. T., Soriani, H. H., De Conti, L., Mimmo, T., Cesco, S., \& Brunetto, G. (2016). The potential of Zea mays L. in remediating copper and zinc contaminated soils for grapevine production. Geoderma, 262, 52-61. https://doi.org/10.1016/j.geoderma.2015.08.015

Tripathi, R. D., Dwivedi, S., Shukla, M. K., Mishra, S., Srivastava, S., Singh, R., Rai, U. N., \& Gupta, D. K. (2008). Role of blue green algae biofertilizer in ameliorating the nitrogen demand and fly-ash stress to the growth and yield of rice (Oryza sativa L.) plants. Chemosphere, 70, 1919-1929. https://doi.org/10.1016/j.chemosphere.2007.07.038

Vanacek, P., Sebestova, E., Babkova, P., Bidmanova, S., Daniel, L., \& Dvorak, P. (2018). Exploration of enzyme diversity by integrating bioinformatics with expression analysis and biochemical characterization. ACS Catalysis, 8, 2402-2412. https://doi.org/10.1021/acscatal.7b03523

Vargas-García, M. C., Suárez-Estrella, F., López, M. J., \& Moreno, J. (2012). Bioremediation of heavy metals with microbial isolates. Universidad de Almeria, Crta.

Vullo, D. L., Ceretti, H. M., Hughes, E. A., Ramyrez, S., \& Zalts, A. (2008). Cadmium, zinc and copper biosorption mediated by Pseudomonas veronii 2E. Bioresource Technology, 99(13), 5574-5581. https://doi.org/10.1016/j.biortech.2007.10.060

Whelan, M. J., Coulon, F., Hince, G., Rayner, J., McWatters, R., Spedding, T., \& Snape, I. (2015). Fate and transport of petroleum hydrocarbons in engineered biopiles in polar regions. Chemosphere, 131, 232-240. https://doi.org/10.1016/j.chemosphere.2014.10.088

Wichard, T., Bellenger, J.-P., Morel, F. M. M., \& Kraepiel, A. M. L. (2009). Role of the siderophore azotobactin in the bacterial acquisition of nitrogenase metal cofactors. Environmental Science \& Technology, 43(19), 7218-7224.

https://doi.org/10.1021/es8037214

Yancheshmeh, J. B., Khavazi, K., Pazira, E., \& Solhi, M. (2011). Evaluation of inoculation of plant growth-promoting rhizobacteria on cadmium and lead uptake by canola and barley. African Journal of Microbiology Research, 5(14), 1747-1754.

Yang, G., Chen, F., \& Yang, Z. (2012). Electrocatalytic oxidation of hydrogen peroxide based on the shuttlelike Nano-CuOModified electrode. International Journal of Electrochemistry, 2012, 194183. https://doi.org/10.1155/2012/194183

Yin, X. X., Wang, L. H., Bai, R., Huang, H., \& Sun, G. X. (2012). Accumulation and transformation of arsenic in the bluegreen alga Synechocysis sp. PCC6803. Water Air and Soil Pollution, 223(3), 1183-1190.

https://doi.org/10.1007/s11270-011-0936-0

Zhang, Q., \& Xiu, Z. (2009). Metabolic pathway analysis of glycerol metabolism in Klebsiella pneumoniae incorporating oxygen regulatory system. Biotechnology Progress, 25, 103-115. https://doi.org/10.1002/btpr.70

Zhang, S., Wen, J., Hu, Y., Fang, Y., Zhang, H., Xing, L., Wang, Y., \& Zeng, G. (2019). Humic substances from green waste compost: An effective washing agent for heavy metal (Cd, Ni) removal from contaminated sediments. Journal of Hazardous Materials, 366, 210-218.

https://doi.org/10.1016/j.jhazmat.2018.11.103

Zhou, D., Li, Y., Zhang, Y., Zhang, C., Li, X., Chen, Z., Huang, J., Li, X., Flores, G., \& Kamon, M. (2014). Column test-based optimization of the permeable reactive barrier (PRB) technique for remediating groundwater contaminated by landfill leachates. Journal of Contaminant Hydrology, 168, 1-16. https://doi.org/10.1016/j.jconhyd.2014.09.003

Zhu, Y., Klompe, S. E., Vlot, M., van der Oost, J., \& Staals, R. H. (2018). Shooting the messenger: RNA-targetting CRISPR-Cas systems. Bioscience Reports, 38(3), BSR20170788. https://doi.org/10.1042/BSR20170788 